\title{
Kejang Post Partum di Rumah Sakit Tipe B: sebuah Manajemen Kasus Multidisiplin
}

\author{
Ketut Mahendera Barata ${ }^{1}$, Mariza Fitriati ${ }^{2}$, Hisbullah ${ }^{3}$, Faisal $^{3}$, Haizah Nurdin ${ }^{3}$ \\ ${ }^{1}$ Peserta program Sp2 Konsultan Intensive Care, Departemen Anestesiologi dan Terapi Intensif Fakultas \\ Kedokteran Universitas Hassanudin - RSUP dr.Wahidin Sudirohusodo, Ujungpadang, ${ }^{2}$ Staf pengajar \\ Departemen Anestesiologi dan Terapi Intensif Fakultas Kedokteran Universitas Airlangga - RSUD dr.Soetomo, \\ Surabaya, ${ }^{3}$ Staf pengajar Departemen Anestesiologi dan Terapi Intensif Fakultas Kedokteran Universitas \\ Hassanudin - RSUP dr.Wahidin Sudirohusodo, Ujungpadang
}

\begin{abstract}
Abstrak
Kejang post partum masih merupakan kasus utama penyebab morbiditas dan mortalitas maternal diseluruh dunia. Diagnosis banding penyebab kejang antara lain kejang akut, gangguan metabolik, hipoglikemi dan hipo/ hipernatremia, jejas otak traumatik, iskemia otak sesaat ataupun cerebrovasculair accident, perdarahan intrakranial, perdarahan subarachnoid, meningitis, ensefalitis, eklampsia, gejala akut kecanduan alkohol, gejala akut kecanduan benzodiazepine atau barbiturate, dural puncture, dan posterior reversible encephalopathy syndrome (PRES). Pada pasien ini terjadi kejang pada hari kedelapan post partum, dengan penyebab utama kejang berasal dari masalah kardiovaskular. Manajemen kejang pada pasien ini dimulai dengan upaya resusitasi cairan, dilanjutkan pengelolaan dukungan airway-breathing-circulation, dan kemudian penyingkiran kandidat diagnosis terhadap infeksi Covid-19, Mendelson syndrome, infeksi lain, gangguan keseimbangan elektrolit, dll. Kerjasama multidisiplin dokter spesialis sangat membantu pencapaian kesembuhan, meskipun masih perlu dilakukan pemeriksaan lanjutan terutama bila ada perencanaan kehamilan berikutnya.
\end{abstract}

Kata kunci: kejang post partum, kardiomiopati post partum, desaturasi

\section{Post Partum Seizures in Type B Hospital: A Multidisciplinary Case Management}

\begin{abstract}
Post partum seizures are still the leading cases of maternal morbidity and mortality worldwide. The differential diagnosis of the causes of seizures are acute seizures, metabolic disorders, hypoglycemia and hypo/hypernatremia, traumatic brain stroke, temporary brain ischemia or cerebrovascular accident, intracranial hemorrhage, subarachnoid hemorrhage, meningitis, encephalitis, eclampsia, acute symptoms of alcohol addiction, acute symptoms of benzodiazepine or barbiturate addiction, dural puncture, dan posterior reversible encephalopathy syndrome (PRES). In this patients there is a seizure on the eighth day of post partum, with the main cause coming from cardiovasculair problems. Seizure management in these patients begins with fluid resuscitation efforts, continued with airway-breathing-circulation support, and then removal of diagnosis candidates : Covid-19 infection, Mendelson syndrome, other infections, electrolyte balance disorders, etc. Multidisciplinary cooperation of the specialist doctors is very helpful in achieving recovery, although it still needs follow-up examination especially when there is planning for the next pregnancy
\end{abstract}

Key words: post partum seizure, post partum cardiomyopathy, desaturation 


\section{Pendahuluan}

Kejang post partum masih merupakan kasus utama penyebab morbiditas dan mortalitas maternal diseluruh dunia. Karena itu pengenalan individu dengan risiko tinggi sangat penting. ${ }^{1}$ Diagnosis banding kejang amat beragam antara lain kejang akut, gangguan metabolik, hipoglikemi dan hipo/hipernatremia, jejas otak traumatik, iskemia otak sesaat ataupun cerebrovasculair accident, perdarahan intrakranial, perdarahan subarachnoid, meningitis, ensefalitis, eklampsia, gejala akut kecanduan alkohol, dan gejala akut kecanduan benzodiazepine atau barbiturate. ${ }^{2}$

Terdapat laporan kasus kejang pada hari ketujuh post partum yang mendahului kardiomiopati pada pasien akibat gangguan hipertensi. Gangguan hipertensi pada kehamilan seperti pada preeklampsia dan eklampsia, banyak dihubungkan dengan peripartum kardiomiopati. Karena preeklampsia dan eklampsia dapat terjadi pada masa post partum lanjut, maka diagnosis ini sering mendapat perhatian klinisi. ${ }^{3}$ Kejadian kejang post partum lanjut juga pernah terjadi pada hari kesembilan, yang kemudian dilaporkan disebabkan oleh posterior reversible encephalopathy syndrome (PRES). ${ }^{4}$ Diagnosis PRES membutuhkan piranti canggih CT-scan atau MRI. ${ }^{4-7}$ PRES dapat merupakan kondisi tersendiri, maupun terkait eklampsia. ${ }^{6,7}$ Penyebab kejang post partum yang lain yang patut mendapat perhatian adalah dural puncture. ${ }^{8-10}$ Pada kasus ini, pasien mengalami kejang pada hari kedelapan post partum seksio sesarea tanpa gejala pre-eklampsia atau eklampsia (kecuali proteinuria), dan tanpa gejala neurologis. Kondisi $\mathrm{X}$-foto paru dengan gambaran perselubungan bilateral membuat kecurigaan infeksi Covid-19 dan Mendelson syndrome sempat mengemuka.

\section{Kasus}

\section{Riwayat Penyakit}

Pasien seorang wanita, usia 28 tahun, gravida 0 para 2 abortus 0 post partum dengan seksio sesarea 8 hari, berat badan $80 \mathrm{~kg}$, dan tinggi badan $165 \mathrm{~cm}$. datang di UGD pada tanggal 29 April 2021 sebagai pasien rujukan dari rumah sakit tipe $\mathrm{C}$ (berjarak \pm 2 jam perjalanan darat) dengan diagnosis rujukan : pneumonia dan kardiomegali. Diketahui juga bahwa pasien kejang sekitar 18 jam sebelum tiba di UGD rumah sakit tujuan rujukan (tipe B). Kejang terjadi dua kali dengan durasi lebih kurang 2 menit dan 10 menit, lidah pasien sempat tergigit dua kali, disertai batuk dengan keluar darah merah segar 3 kali, namun tidak ada demam. Pasien juga merasa mual dan beberapa kali muntah. Sebelumnya pasien menjalani operasi seksio sesarea pada 21 April 2021 dengan indikasi G1P1, umur kehamilan 39 minggu, lilitan tali pusat. Riwayat preeklampsia, hipertensi, kejang sebelumnya, diabetes, dan asma bronchiale disangkal.

\section{Pemeriksaan Fisis}

Pada pemeriksaan fisik di UGD rumah sakit tujuan rujukan didapatkan pasien dengan skala kesadaran Glasgow Coma Scale (GCS) 15, E4M6V5, jalan nafas bebas, tekanan darah $140 / 88 \mathrm{mmHg}$, nadi 130 kali per menit, frekuensi nafas 40 kali per menit pada pemberian $\mathrm{O}_{2}$ lewat masker NRM tersambung Jackson-Rees $15 \mathrm{lpm}$, namun $\mathrm{SpO}_{2}$ hanya tercapai $90 \%$. Suhu tubuh $36^{\circ} \mathrm{C}$, konjungtiva tidak anemis, sklera tidak ikterik, tidak terlihat sianosis, tapi terlihat sesak. Pemeriksaan paruparu terdengar ronchi di kedua lapang paru tanpa wheezing. Akral dingin, kering, tidak edema. Pemeriksaan suara jantung normal, perut dalam batas normal dengan luka pasca seksio sesarea.

\section{Pemeriksaan Penunjang}

Hasil pemeriksaan penunjang di RS perujuk yang dibawakan pada pasien didapatkan kadar hemoglobin 12,6 gr/dL, hematokrit 39,8\%,

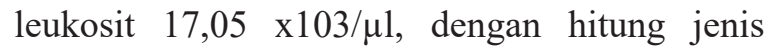
eosinofil $3 \%$, basofil $0,10 \%$, neutrofil $69 \%$, limfosit $22 \%$, monosit $5 \%$, sehingga Netrofil to Limfosit Ratio (NLR) didapatkan 3,13, sedangkan trombosit $515 \times 103 / \mu 1$. Laju endap darah $25 \mathrm{~mm} /$ jam, pemeriksaan antigen SARS Cov-2 negatif. Pemeriksaan protein urine positif $3(+3)$. Foto thorax di RS perujuk tanggal 29 April 2021 didapatkan pembesaran cardiac to thoracic ratio (CTR) yaitu $62 \%$, disertai bercak infiltrat pada kedua lapang paru dengan sinus costophrenicus masih terlihat tajam. Kesimpulan ahli radiologi adalah gambaran pneumonia dan kardiomegali. 


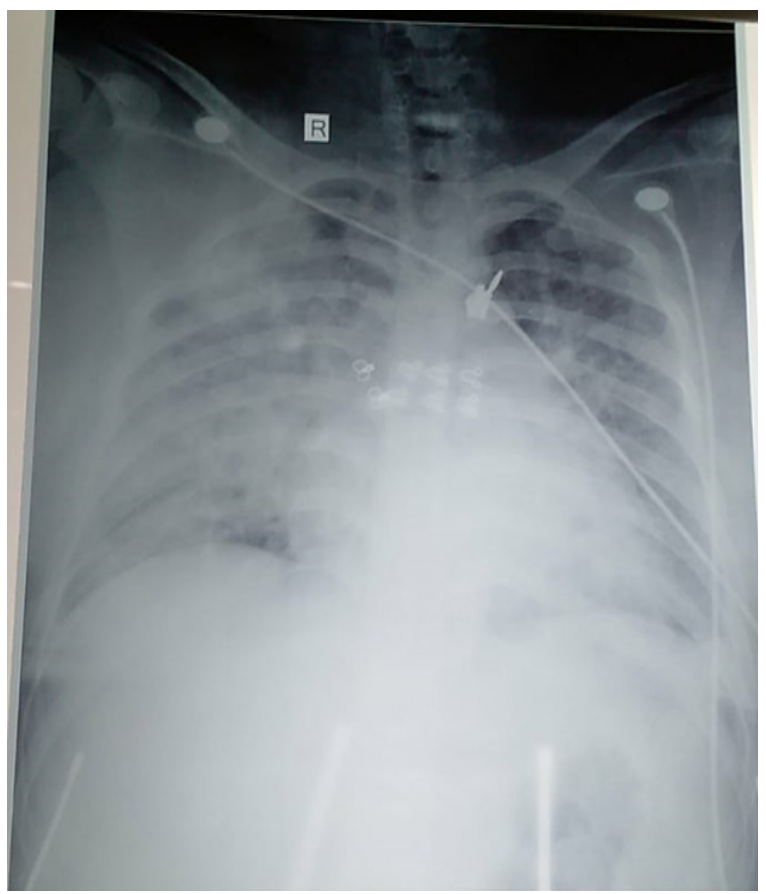

Gambar 1. Thorax foto dari RS perujuk

Pasien didiagnosis oleh dokter jaga UGD dengan observasi dyspnea, pneumonia, probable Covid-19, dan seizure post partum. Dokter jaga UGD kemudian melakukan konsultasi ke DPJP SpOG dan mendapat petunjuk untuk mengikuti saran terapi dokter anestesi. Konsultasi kepada dokter anestesi menghasilkan rencana terapi infus RL, mempertahankan oksigenasi, transport ke ICU, dan rencana diintubasi di ICU.

\section{Pengelolaan di ICU}

Sesuai rencana, kemudian pasien dipindahkan ke ICU, namun sesaat pasien tiba di ICU terjadi perubahan kondisi. Tekanan darah menjadi $66 / 50$ mmHg, laju nadi 150-160 kali permenit, tidak kuat angkat, akral dingin dan basah. Oksigen telah diberikan dengan $\mathrm{O}_{2}$ masker tersambung Jackson-Rees 15 lpm, nafas spontan 35-40 kali permenit, dan $\mathrm{SpO}_{2}$ menurun menjadi $87 \%$. Terdengar ronchi tanpa wheezing. Kesadaran menurun menjadi E3V4M5, dan pasien terlihat cyanosis.

Kondisi ini segera direspon dengan pemberian ekstra $500 \mathrm{ml}$ gelofusin secara cepat, sembari dilakukan persiapan intubasi sesuai protokol Covid-19. Pasien kemudian diintubasi dengan bantuan obat midazolam $3 \mathrm{mg}$ dan rocuronium $50 \mathrm{mg}$ dan disambungkan pada ventilator dengan pengaturan BPAP, Pins 27, Pasb 16, rate 29, PEEP 11, trigger 2, $\mathrm{FIO}_{2} 100 \%$, didapatkan hasil luaran Vte 400-470 ml, laju napas 29x/m, $\mathrm{SpO}_{2}$ $83-85 \%$, terlihat pink froothy sputum pada pipa endotrakeal. Tekanan darah menjadi 100-130 / 70 $\mathrm{mmHg}$, mean arterial pressure (MAP) $80 \mathrm{mmHg}$, laju nadi $160 \mathrm{x} / \mathrm{m}$, kuat angkat, akral dingin kering, terpasang norepinephrine $100 \mu \mathrm{g} / \mathrm{kgBB} /$ jam. Kesadaran dalam pengaruh sedasi E1VxM1, dengan pupil bulat isokor, reflek cahaya $+/+$. Urine terukur lewat kateter sejumlah $200 \mathrm{ml}$, terkesan hematuria. Abdomen soeffel, datar, terlihat luka bekas seksio sesarea, bising usus masih terdengar. Pasien masih terlihat cyanosis dan ada edema. Pipa nasogastrik dipasang setelah intubasi, dari pipa nasogastrik keluar cairan $300 \mathrm{ml}$ hijau kecoklatan. Kateter vena sentral (CVC) dipasang di vena femoralis kanan, Untuk masalah takikardia (supraventricular takikardia) diberikan injeksi amiodarone $150 \mathrm{mg}$ dalam 1 jam, diikuti $300 \mathrm{mg}$ dalam 3 jam. Untuk membantu kendali pernapasan diberikan rocuronium $20 \mathrm{mg} / \mathrm{jam}$, morfin $1 \mathrm{mg} / \mathrm{jam}$, dan midazolam $5 \mathrm{mg} / \mathrm{jam}$. Masalah retensi (cairan di pipa nasogastrik) diupayakan diatasi dengan pantoprazole 2 x $40 \mathrm{mg}$ dan prokinetik gastrointestinal metoclopramide 2 $\mathrm{x} 10 \mathrm{mg}$.

Beberapa pemeriksaan penunjang kemudian ditambahkan : analisa gas darah, fungsi hati, fungsi ginjal, faal pembekuan darah, d-dimer, laktat, c-reactive protein (CRP), procalcitonin, polymerase chain rection (PCR) Covid-19, interleukin-6, kultur darah dan sputum. Hasil pemeriksaan penunjang menunjukkan $\mathrm{pH} 7,21$, $\mathrm{pCO}_{2} 43 \mathrm{mmHg}, \mathrm{pO}_{2} 56 \mathrm{mmHg}, \mathrm{HCO}_{3}-17,6$ $\mathrm{mmHg}, \mathrm{BE}-10,4 \mathrm{meq} / \mathrm{L}, \mathrm{SaO}_{2} 83 \%, \mathrm{AaDO}_{2}$ $603 \mathrm{mmHg}$, dan GDS $109 \mathrm{mg} / \mathrm{dL}$. Pemeriksaan elektrolit natrium $133 \mathrm{meq} / \mathrm{L}$, Kalium 4,7 meq/L, dan Cl $100 \mathrm{meq} / \mathrm{L}$. Kadar SGOT 36 IU/Ldan SGPT $16 \mathrm{IU} / \mathrm{L}$, bilirubin $0,94 \mathrm{mg} / \mathrm{dl}$, dan albumin $2,6 \mathrm{~g} /$ dL. PPT 17,0 detik, APTT 38,8 detik, INR 1,68, laktat $3,3 \mathrm{mg} / \mathrm{dL}$ dan procalcitonin $>200 \mathrm{ng} / \mathrm{mL}$.

\section{Perawatan Hari ke-1}

Oksigen diberikan lewat pipa endotrakeal, disambungkan ventilator dengan pengaturan 
BPAP, Pins 27, Pasb 16, rate 29, PEEP 11, trigger 2, $\mathrm{FIO}_{2} 100 \%$ memberikan hasil volume ekspirasi tidal $400-470 \mathrm{ml}$, laju napas $29 \mathrm{x} / \mathrm{m}, \mathrm{SpO}_{2} 83-$ $85 \%$, dan masih didapatkan pink froothy sputum. Tekanan darah 100-120/70-80 mmHg, MAP 110 $\mathrm{mmHg}$, laju nadi $160-170 \mathrm{x} / \mathrm{m}$, teraba nadi kuat angkat, terpasang norepinephrine $100 \mu \mathrm{g} / \mathrm{kgBB} /$ menit. Suhu tubuh $39,5^{\circ} \mathrm{C}$. Kesadaran masih dalam pengaruh sedasi, dengan GCS E1VxM1, pupil bulat isokor dan reflek cahaya positif. Produksi urine lebih kurang $60 \mathrm{ml} / \mathrm{jam}$. Abdomen tampak luka pasca seksio sesarea, bising usus ada. Didapatkan edema ekstremitas tanpa sianosis. Assessment: pasca kejang + penurunan kesadaran (pasca seksio sesarea 8 hari), disertai desaturasi, pneumonia, kardiomegali, takikardia (dengan gambaran supraventriculair tachycardia, SVT), hipertermia, dan proteinuria $(+3)$. Pasien mendapat terapi sonde D5\% 6x $50 \mathrm{ml}$, cairan intravena RL $500 \mathrm{cc} / 24 \mathrm{jam}$, pelumpuh otot rocuronium $20 \mathrm{mg} / \mathrm{jam}$, analgesik morfin $1 \mathrm{mg} /$ jam, sedasi midazolam $2 \mathrm{mg}$ /jam. Posisi head-up $30 \mathrm{o}$, anti-ulcer pantoprazole $2 \times 40 \mathrm{mg}$, prokinetik gastrointestinal metoclopramide $2 \times 10 \mathrm{mg}$, antibiotika profilaksis levofloxacine $1 \times 750 \mathrm{mg}$, paracetamol intravena $4 \times \mathrm{I}$ gram, $\mathrm{KCl}$ intravena $50 \mathrm{meq} / 24 \mathrm{jam}$, dan ivabradine oral/sonde $2 \times 5$ mg. Injeksi amiodarone dilanjutkan dengan 300 $\mathrm{mg} / 6$ jam untuk terapi SVT.

Pemeriksaan penunjang, baik pemeriksaan ulang maupun baru, yang telah dimintakan sebelumnya memberikan hasil sebagai berikut : Natrium 146 meq/L, Kalium 2,8 meq/L, Cl $111 \mathrm{meq} / \mathrm{L}, \mathrm{Ca} 9,9$ meq/L, P 5,1 meq/L, Mg 2,5 meq/L. Kadar SGOT $36 \mathrm{IU} / \mathrm{L}$ dan SGPT $18 \mathrm{IU} / \mathrm{L}$, dan albumin 3,95 g/ dL. Ureum 25,2 mg/dL dan kreatinin $0.95 \mathrm{mg} / \mathrm{dL}$. PPT 15,4 detik, APTT 30,4 detik, BT 3 detik, CT 13 detik, INR 1,27, d-dimer 13,02 ng/ml , IL-6 $297,3 \mathrm{pg} / \mathrm{mL}$, CRP 77,2 mg/L dan procalcitonin $>200 \mathrm{ng} / \mathrm{mL}$. PCR Covid-19 negatif. Karena d-dimer meningkat, maka ditambahkan heparin $5000 \mathrm{IU}$ bolus, diteruskan dengan $500 \mathrm{IU} / \mathrm{jam}$.

Beberapa konsultasi dilakukan untuk membantu evaluasi pasien. Dokter spesialis jantung yang dikonsultasikan untuk evaluasi kinerja jantung dengan echocardiography, memberikan saran melanjutkan terapi amiodarone dan ditambahkan tablet ivabradine $2 \times 5 \mathrm{mg}$. Dokter spesialis paru dalam konsultasi juga memberikan tambahan terapi (sesuai dengan persangkaan telah terjadi Mendelson syndrome) obat steroid indexon 2x6 $\mathrm{mg}$, bisolvon $3 \times 4 \mathrm{mg}$, dan antibiotika profilaksis meropenem $3 \times 1$ gram. Karena terjadi peningkatan suhu tubuh pasien yang dicurigai terjadi akibat mastitis, maka hal ini dikonsultasikan kepada dokter spesialis Kebidanan dan Kandungan dengan usulan diberikan bromocriptine, namun diputuskan ditunda oleh dokter tersebut karena

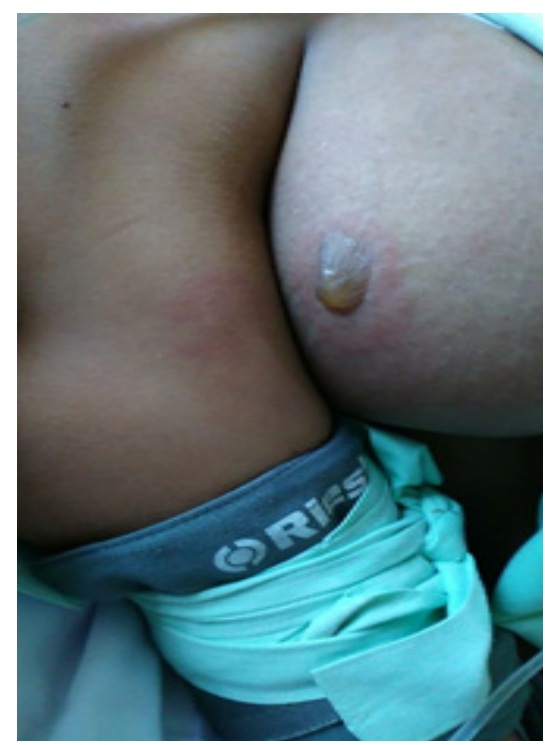

Gambar 2. Mastitis.

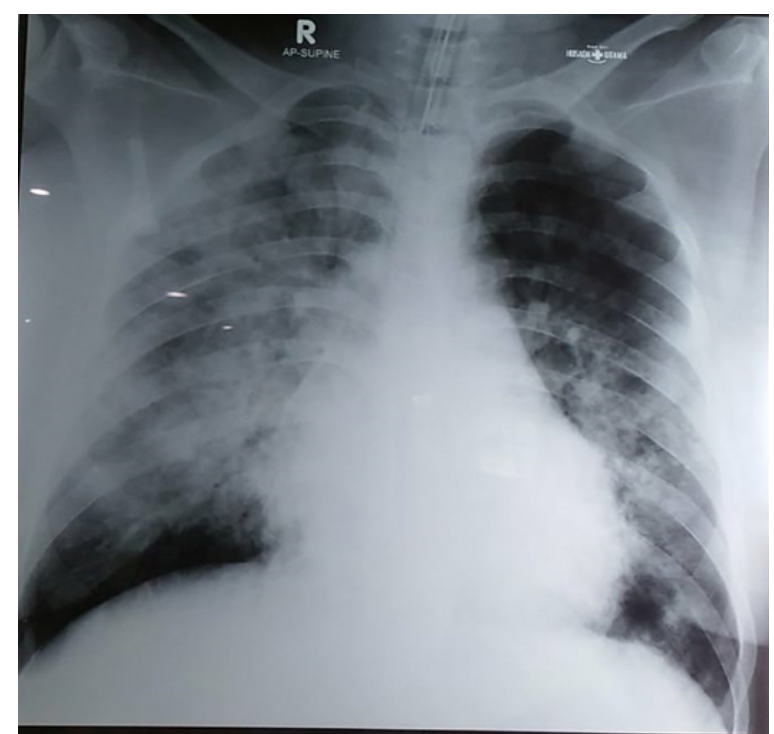

Gambar 3. Thorax Foto hari Perawatan Pertama (Pasca Intubasi) 
masih belum dapat disingkirkan kemungkinan permasalahan intrakranial.

\section{Perawatan Hari ke-2}

Oksigen masih diberikan lewat pipa endotrakeal, dengan pengaturan ventilator BPAP, Pins 26, Pasb 15, rate 25, PEEP 11, trigger 2, $\mathrm{FIO}_{2} 100 \%$ memberikan hasil volume ekspirasi tidal 433-455 $\mathrm{ml}$, laju napas $25 \mathrm{x} / \mathrm{m}, \mathrm{SpO}_{2}$ 100\%. Didapatkan sputum mukopurulen disertai garis-garis darah. Tekanan darah 118-135/70-80 mmHg, laju nadi 122-134 x/m, dengan terpasang Norepinephrine $100 \mu \mathrm{g} / \mathrm{kg} \mathrm{BB} / \mathrm{menit}$, teraba nadi kuat angkat. Suhu $38-40^{\circ} \mathrm{C}$. Kesadaran masih dalam pengaruh sedasi, GCSE1VxM1, pupil bulat isokor dan reflek cahaya positif. Produksi urine $50 \mathrm{ml} / \mathrm{jam}$. Pada abdomen tampak luka pasca seksio sesarea, bising usus positif. Didapatkan edema ekstremitas tanpa sianosis. Assessment: pasca kejang + penurunan kesadaran (pasca seksio sesarea 9 hari), disertai pneumonia, kardiomegali, takikardia (gambaran EKG supraventrikular takikardia), hipertermia, dan proteinuria $(+3)$. Terapi : sonde dingin D5\% 6x200 ml, cairan intravena RL $500 \mathrm{cc} / 24 \mathrm{jam}$, pelumpuh otot rocuronium $20 \mathrm{mg} / \mathrm{jam}$, analgesik morfin dihentikan, sedasi midazolam $2 \mathrm{mg} / \mathrm{jam}$. Posisi head-up 30o, anti-ulcer pantoprazole $2 \times 40$ $\mathrm{mg}$, prokinetik gastrointestinal metoclopramide 2x10 mg, antibiotika profilaksis levofloxacine $1 \times 750 \mathrm{mg}$ kombinasi dengan meropenem 3 x 1 g, indexon $2 \times 6 \mathrm{mg}$, bisolvon $3 \times 4 \mathrm{mg}$, paracetamol intravena $4 \times \mathrm{I}$ gram, $\mathrm{KCl}$ intravena $50 \mathrm{meq} / 24 \mathrm{jam}$, dan ivabradine oral/sonde $2 \times 5$ mg. Norepinephrine direncanakan diturunkan bertahap, dikombinasikan dengan dobutamine $3 \mu \mathrm{g} / \mathrm{kgBB} / \mathrm{jam}$. Heparin diberikan $500 \mathrm{IU} / \mathrm{jam}$. Suhu tubuh mulai terkendali dan dokter spesialis Kebidanan dan Kandungan setelah melakukan evaluasi menemukan bahwa tidak didapatkan tanda-tanda masalah intrakranial, setuju pemberian bromocriptine (cripsa) tablet sebesar $1 \times 2,5 \mathrm{mg}$.

Pemeriksaan penunjang ulangan memberikan hasil $\mathrm{pH} 7,29, \mathrm{pCO}_{2} 54 \mathrm{mmHg}, \mathrm{pO}_{2} 128 \mathrm{mmHg}$, $\mathrm{HCO} 3-25,3 \mathrm{mmHg}, \mathrm{BE}-1,1 \mathrm{mEq} / \mathrm{L}, \mathrm{SaO}_{2} 98 \%$, dan $\mathrm{AaDO}_{2}$ 51,8 mmHg, natrium $146 \mathrm{meq} / \mathrm{L}$, kalium 3,2 meq/L, dan Ca $0,98 \mathrm{meq} / \mathrm{L}$, dan laktat $2,9 \mathrm{mg} / \mathrm{dL}$. Pemeriksaan echocardiography menunjukkan penurunan fungsi sistolik ventrikel kiri menjadi 36\%, relaksasi abnormal fungsi diastolik, dan penurunan fungsi sistolik ventrikel kanan. Analisa segmental ventrikel kiri akinetik inferoseptal (B-M), segmen lain hipokinetik global. Terdapat left ventrikel hyperthrophy. Kesimpulan echocardiography adalah cardiomyopathy, dan dokter spesialis jantung menyarankan lanjutan terapi ivabradine disamping terapi lain yang telah dilakukan.

\section{Perawatan Hari ke-3}

Oksigen lewat pipa endotrakeal dengan ventilator pengaturan BPAP, Pins 26, Pasb 15, rate 25, PEEP 11, trigger 2, $\mathrm{FIO}_{2} 90 \%$ memberikan hasil volume ekspirasi tidal $416-525 \mathrm{ml}$, laju napas $25 \mathrm{x} / \mathrm{m}, \mathrm{SpO}_{2} 97-99 \%$, masih terdapat sputum mukopurulen. Tekanan darah 100-130/70-80 $\mathrm{mmHg}$, laju nadi $100-118 \mathrm{x} / \mathrm{m}$, teraba nadi kuat angkat, dengan terpasang norepinephrine $50 \mu \mathrm{g} /$ $\mathrm{kg} \mathrm{BB} /$ menit, dobutamin $3 \mu \mathrm{g} / \mathrm{kgBB} / \mathrm{jam}$, dan amiodarone $450 \mathrm{mg} / 12 \mathrm{jam}$. Suhu $38-38,5^{\circ} \mathrm{C}$, Kesadaran masih dalam pengaruh sedasi, dengan GCS E1VxM1, pupil bulat isokor dan reflek cahaya positif. Produksi urine lebih kurang 60 $\mathrm{ml} /$ jam. Abdomen tampak luka post SC, bising usus ada. Didapatkan edema ekstremitas tanpa sianosis.

Assessment: pasca kejang + penurunan kesadaran (pasca seksio sesarea hari ke 10), disertai pneumonia, kardiomegali, takikardia (dengan gambaran EKG takikardia supraventrikular), hipernatremi, hipokalemi, dan proteinuria $(+3)$. Terapi sonde dingin D5\% 6×200 ml, cairan intravena RL $500 \mathrm{cc} / 24 \mathrm{jam}$, pelumpuh otot rocuronium $20 \mathrm{mg} / \mathrm{jam}$, sedasi midazolam $2 \mathrm{mg} / \mathrm{jam}$. Posisi head-up 30o, anti-ulcer pantoprazole $2 \times 40 \mathrm{mg}$, prokinetik gastrointestinal metoclopramide $2 \times 10 \mathrm{mg}$, antibiotika profilaksis levofloxacine $1 \times 750 \mathrm{mg}$ dan meropenem $3 \times 1 \mathrm{~g}$, indexon $2 \times 6 \mathrm{mg}$, bisolvon $3 \times 4 \mathrm{mg}$, paracetamol intravena 4xI gram, metamizole $3 \times 500 \mathrm{mg}$, $\mathrm{KCl}$ intravena $50 \mathrm{meq} / 24 \mathrm{jam}$, ivabradine oral/ sonde $2 \times 5 \mathrm{mg}$, dan tablet peroral cripsa $1 \times 2,5 \mathrm{mg}$ Norepinephrine diturunkan bertahap, kombinasi dengan dobutamine $3 \mu \mathrm{g} / \mathrm{kgBB} / \mathrm{jam}$. Heparin diberikan500IU/jam,injeksifurosemide $3 \mathrm{mg} / \mathrm{jam}$. Pemeriksaan penunjang ulangan memberikan 
hasil $\mathrm{pH} 7,42, \mathrm{pCO}_{2} 37 \mathrm{mmHg}, \mathrm{pO}_{2} 250 \mathrm{mmHg}$, HCO3- 23, 8 mmHg, $\mathrm{BE} 0 \mathrm{mEq} / \mathrm{L}, \mathrm{SaO}_{2} 100 \%$, dan AaDO2 $345 \mathrm{mmHg}$. Natrium $148 \mathrm{meq} / \mathrm{L}$, kalium 3,1 meq/L, Ca 0,46 meq/L, Cl 114 $\mathrm{meq} / \mathrm{L}$ dan laktat $2,3 \mathrm{mg} / \mathrm{dL}$. Albumin $3,38 \mathrm{~g} /$ $\mathrm{dL}$, BUN 41,2 mg/dL, dan kreatinin 1,31 mg/ dL. Pemeriksaan mikrobiologi memberikan hasil bahwa pewarnaan BTA terhadap sputum negatif, kultur urine tidak didapatkan pertumbuhan kuman, pewarnaan $\mathrm{KOH}$ sputum negatif, pewarnaan gram terhadap sputum juga tidak didapatkan kuman.

\section{Perawatan Hari ke-4}

Oksigen masih lewat pipa endotrakeal, disambungkan ventilator dengan mode BPAP, Pins 26, Pasb 15, rate 25, PEEP 11, trigger 2, $\mathrm{FIO}_{2}$ 65\% mendapat hasil volume ekspirasi tidal 480-641 ml, laju napas $25 \mathrm{x} / \mathrm{m}, \mathrm{SpO}_{2}$ 92-100\%. Sputum mukopurulen berkurang. Tekanan darah 105-145/65-80 $\mathrm{mmHg}$, laju nadi $75-110 \mathrm{x} / \mathrm{m}$, teraba nadi kuat angkat, terpasang norepinephrine $25 \mu \mathrm{g} / \mathrm{kgBB} /$ menit dan dobutamin $3 \mu \mathrm{g} / \mathrm{kgBB} / \mathrm{jam}$. Suhu tubuh $37-37,5^{\circ} \mathrm{C}$. Kesadaran mulai meningkat karena pengaruh sedasi dikurangi, GCS E4VxM6, pupil bulat isokor dan reflek cahaya positif. Produksi urine lebih kurang $80 \mathrm{ml} / \mathrm{jam}$. Abdomen tampak luka post SC, bising usus ada. Didapatkan edema ekstremitas tanpa sianosis. Assessment : pasca kejang + penurunan kesadaran (pasca seksio sesarea hari ke 11), pneumonia, kardiomegali, takikardia, hipernatremi, dan proteinuria $(+3)$. Terapi : sonde D5\% bergantian dengan enterasole $6 \times 200 \mathrm{ml}$, cairan intravena D5\% $500 \mathrm{cc} / 24 \mathrm{jam}$, pelumpuh otot rocuronium $10 \mathrm{mg} / \mathrm{jam}$ (saat habis dihentikan, dipersiapkan weaning), sedasi midazolam $2 \mathrm{mg} / \mathrm{jam}$. Posisi head-up $30^{\circ}$, anti-ulcer pantoprazole 2 x $40 \mathrm{mg}$, prokinetik gastrointestinal metoclopramide 2 x $10 \mathrm{mg}$, antibiotika profilaksis levofloxacine 1 x $750 \mathrm{mg}$ kombinasi dengan meropenem $3 \times 1 \mathrm{~g}$, indexon 2 x $6 \mathrm{mg}$, bisolvon $3 \times 4 \mathrm{mg}$, paracetamol intravena 4 x I gram, metamizole 3 x $500 \mathrm{mg}$, dan ivabradine oral/sonde 2 x $5 \mathrm{mg}$. Norepinephrine diturunkan bertahap. KCL $25 \mathrm{mEq} / 24$ jam, heparin diberikan $500 \mathrm{IU} / \mathrm{jam}$, dan furosemide $3 \mathrm{mg} / \mathrm{jam}$. Tablet peroral cripsa $1 \times 2,5 \mathrm{mg}$, dan digoxin $2 \times 0,25 \mathrm{mg}$.

Pemeriksaan penunjang ulangan memberikan hasil: $\mathrm{pH}$ 7,53, $\mathrm{pCO}_{2} 33 \mathrm{mmHg}, \mathrm{pO}_{2} 251$ $\mathrm{mmHg}, \mathrm{HCO} 327,4 \mathrm{mmHg}, \mathrm{BE} 4,9 \mathrm{mEq} / \mathrm{L}$, $\mathrm{SaO}_{2} 100 \%$, dan $\mathrm{AaDO} 2243 \mathrm{mmHg}$, natrium $148 \mathrm{meq} / \mathrm{L}$, kalium 3,1 meq/L, dan laktat 2,5 $\mathrm{mg} / \mathrm{dL}$. Albumin 3,38 g/dL, BUN 41,2 mg/dL, dan kreatinin 1,31 mg/dL. Pemeriksaan PCR Covid-19 ulang memberikan hasil negatif. Hasil

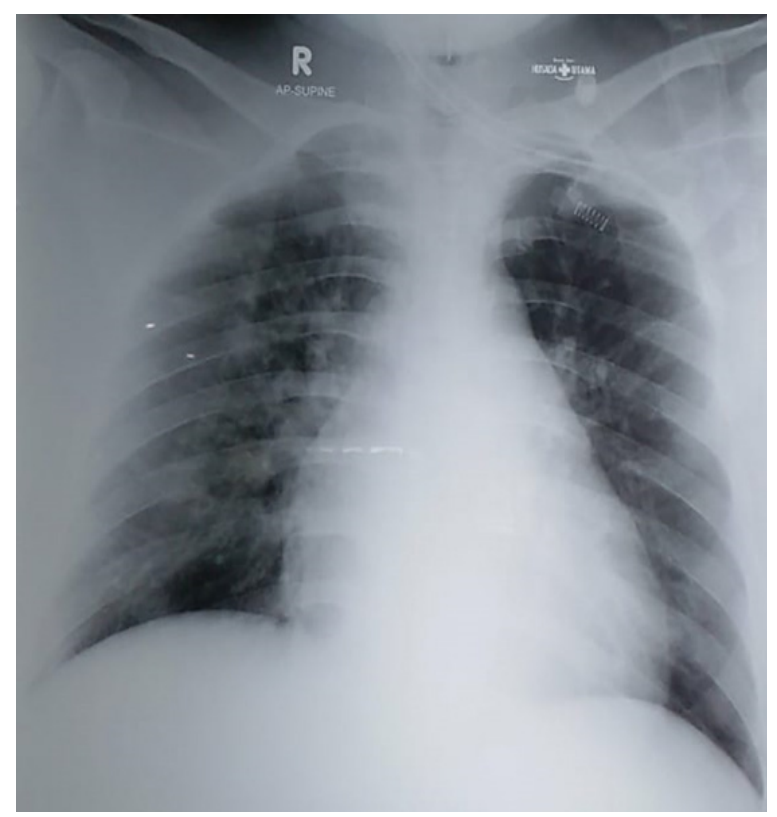

Gambar 4. Thorax Foto hari Perawatan ke-4

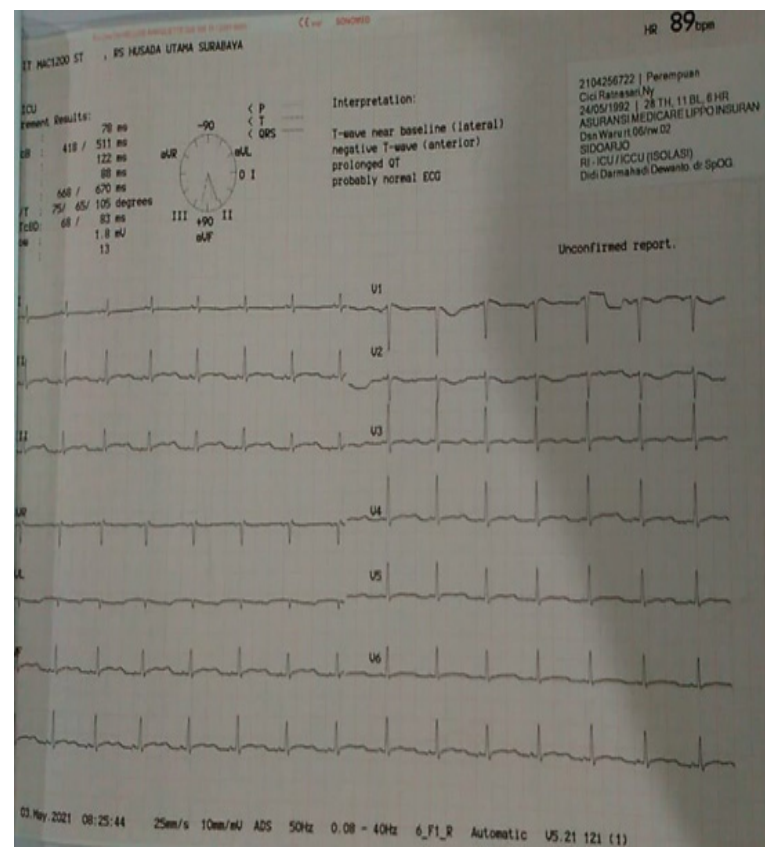

Gambar 5. Elektrokardiografi hari Perawatan ke-4 
kultur sputum tidak ada pertumbuhan kuman.

\section{Perawatan Hari ke-5}

Oksigen diberikan lewat non rebreathing mask (NRM) tersambung pada Jackson Rees $8 \mathrm{lpm}$, laju napas 12-20 x/m, SpO2 96-98\%, sputum mukopurulen minimal. Tekanan darah 95-125/50$65 \mathrm{mmHg}$, laju nadi 90-107 x/m, teraba nadi kuat angkat, dengan terpasang norepinephrine $25 \mu \mathrm{g} /$ $\mathrm{kgBB} / \mathrm{menit}$ dan dobutamin $3 \mu \mathrm{g} / \mathrm{kgBB} / \mathrm{jam}$. Suhu $37-37,3^{\circ} \mathrm{C}$. Kesadaran GCS E4V5M6, pupil bulat isokor dan reflek cahaya positif. Produksi urine lebih kurang $110 \mathrm{ml} / \mathrm{jam}$. Abdomen tampak luka post SC, bising usus ada. Didapatkan edema ekstremitas tanpa sianosis. Assessment: pasca kejang + penurunan kesadaran (pasca seksio sesarea hari ke 12), pneumonia, kardiomegali, takikardia, dan proteinuria $(+3)$. Terapi: sonde enterasole $6 \times 200 \mathrm{ml}$ ditambahkan diet bubur halus, cairan intravena D5\% $500 \mathrm{cc} / 24 \mathrm{jam}$. Dobutamin dan norepinephrine diturunkan bertahap. Posisi head-up $30^{\circ}$, anti-ulcer pantoprazole $2 \times 40 \mathrm{mg}$, prokinetik gastrointestinal metoclopramide $2 \times 10 \mathrm{mg}$, antibiotika profilaksis levofloxacine $1 \times 750 \mathrm{mg}$ dan meropenem $3 \times 1 \mathrm{~g}$, indexon $2 \times 6 \mathrm{mg}$, bisolvon $3 \times 4 \mathrm{mg}$, paracetamol intravena 4xI gram. Metamizole dihentikan. KCL diberikan $25 \mathrm{mEq} / 24$ jam, heparin 500 IU/jam, injeksi furosemide $3 \mathrm{mg} / \mathrm{jam}$. Tablet peroral cripsa $1 \times 2,5 \mathrm{mg}$, dan digoxin $2 \times 0,25 \mathrm{mg}$.

Pasien mulai dipersiapkan untuk pindah ke ruang perawatan biasa. Beberapa pemeriksaan penunjang diulangi dan didapatkan kadar hemoglobin 12,7 gr/dL, hematokrit 39,2\%, leukosit $15,87 \times 103 / \mu 1$. Pemeriksaan gas darah : $\mathrm{pH} 7,49, \mathrm{pCO}_{2} 37 \mathrm{mmHg}, \mathrm{pO}_{2} 116 \mathrm{mmHg}$, $\mathrm{HCO}_{3}-28,2 \mathrm{mmHg}, \mathrm{BE} 4,7 \mathrm{mEq} / \mathrm{L}, \mathrm{SaO}_{2} 99 \%$, dan AaDO2 $265 \mathrm{mmHg}$. Pemeriksaan Natrium $143 \mathrm{meq} / \mathrm{L}$, Kalium 3,0 meq/L, dan Cl $110 \mathrm{meq} / \mathrm{L}$. Albumin 3,42 g/dL, BUN 22,8 mg/dL, dan kreatinin $0,79 \mathrm{mg} / \mathrm{dL}$. APTT 28,5 detik, d-dimer $11,19 \mathrm{ng} / \mathrm{ml}$, laktat $3,3 \mathrm{mg} / \mathrm{dL}$ dan procalcitonin $0,72 \mathrm{ng} / \mathrm{mL}$.

\section{Perawatan Hari ke-6}

Oksigen lewat kateter nasal 2-4 lpm, laju napas 12-20 x/m, $\mathrm{SpO}_{2} 98-100 \%$, sputum tidak ada. Tekanan darah $90-115 / 50-65 \mathrm{mmHg}$, laju nadi
85-100 x/m, teraba nadi kuat angkat, tanpa norepinephrine dan dobutamin. Suhu $37-37,3{ }^{\circ} \mathrm{C}$. Kesadaran GCS E4V5M6, pupil bulat isokor dan reflek cahaya positif. Produksi urine lebih kurang $100 \mathrm{ml} / \mathrm{jam}$. Abdomen tampak luka pasca seksio sesarea, bising usus ada. Didapatkan edema ekstremitas tanpa sianosis. Diagnosis kerja adalah pasca kejang + penurunan kesadaran (pasca seksio sesarea hari ke 13), pneumonia, kardiomegali, dan proteinuria $(+3)$. Diberikan terapi sonde enterasole $6 \times 200 \mathrm{ml}$, diet ditingkatkan ke bubur kasar, cairan intravena D5\% $500 \mathrm{cc} / 24$ jam. Posisi head-up 30o, anti-ulcer pantoprazole 2 x $40 \mathrm{mg}$, prokinetik gastrointestinal metoclopramide $2 \times 10$ $\mathrm{mg}$, antibiotika profilaksis levofloxacine $1 \times 750$ $\mathrm{mg}$ dan meropenem $3 \mathrm{x} 1 \mathrm{~g}$, indexon dihentikan, bisolvon $3 \mathrm{x} 4 \mathrm{mg}$, paracetamol intravena $4 \mathrm{xI}$ gram, KCL dihentikan dan diganti KSR 3x1 tab, heparin dihentikan dan diganti aspilet 1x80 mg. Injeksi furosemide dihentikan. Tablet peroral cripsa $1 \times 2,5 \mathrm{mg}$, dan digoxin $2 \times 0,25 \mathrm{mg}$.

Pemeriksaan mikrobiologi terhadap darah (kultur darah aerob maupun anaerob) memberikan hasil negatif (tidak ada pertumbuhan kuman). Pemeriksaan ulang echocardiography memberikan hasil perbaikan kondisi: katup-katup tak tampak kelainan, dimensi ruang jantung normal, fungsi sistolik LV menurun (50\%), fungsi sistolik RV normal, fungsi diastolik normal, analisa segmental LV normokinetik, terdapat LVH, dan tampak efusi perikardial minimal

\section{Perawatan Hari ke-7}

Oksigen diberikan lewat kateter nasal 2-4 lpm, laju napas 12-20 x/m, $\mathrm{SpO}_{2} 99-100 \%$, sputum tidak ada. Tekanan darah 105-120/55-60 mmHg, laju nadi $70-95 \mathrm{x} / \mathrm{m}$, teraba nadi kuat angka. Suhu tubuh $37-37,3^{\circ} \mathrm{C}$. Kesadaran GCS E4V5M6, pupil bulat isokor dan reflek cahaya positif. Produksi urine lebih kurang $100 \mathrm{ml} / \mathrm{jam}$. Abdomen tampak luka pasca seksio sesarea, bising usus ada. Didapatkan edema ekstremitas tanpa sianosis. Assessment: pasca kejang + penurunan kesadaran (pasca seksio sesarea hari ke 14), disertai pneumonia, kardiomegali, dan proteinuria $(+3)$. Terapi: sonde enterasole $6 \times 200 \mathrm{ml}$ dan bubur kasar, cairan intravena D5\% $500 \mathrm{cc} / 24$ jam. Posisi head-up 30o, anti-ulcer pantoprazole 2 x $40 \mathrm{mg}$, 
prokinetik gastrointestinal metoclopramide $2 \mathrm{x}$ $10 \mathrm{mg}$, antibiotika profilaksis levofloxacine $1 \mathrm{x}$ $750 \mathrm{mg}$ dan meropenem $3 \times 1 \mathrm{~g}$, bisolvon $3 \times 4 \mathrm{mg}$, sdangkan paracetamol dihentikan. Tablet peroral KSR $3 \times 1$ tab, aspilet $1 \times 80 \mathrm{mg}$, cripsa $1 \times 2,5$ $\mathrm{mg}$, dan digoxin $2 \mathrm{x} 0,25 \mathrm{mg}$. Sebelum pasien dipindahkan ke ruang perawatan biasa, dilakukan beberapa pemeriksaan penunjang ulangan : kadar hemoglobin $9,0 \mathrm{gr} / \mathrm{dL}$, hematokrit $27,1 \%$, leukosit $3,1 \times 103 / \mu 1$, trombosit $174 \times 103 / \mu 1$. Pemeriksaan gas darah : $\mathrm{pH} 7,11, \mathrm{pCO}_{2} 17,8 \mathrm{mmHg}, \mathrm{pO}_{2} 78$ $\mathrm{mmHg}, \mathrm{HCO} 3-9,2 \mathrm{mmHg}, \mathrm{BE}-10,3 \mathrm{mEq} / \mathrm{L}$, dan $\mathrm{SaO}_{2}$ 89,9\%. Pemeriksaan elektrolit natrium 140 meq/L, Kalium 4,5 meq/L, dan $\mathrm{Cl} 101 \mathrm{meq} / \mathrm{L}$. BUN $72 \mathrm{mg} / \mathrm{dL}$, kreatinin 2,8 mg/dL, dan laktat $6,2 \mathrm{mg} / \mathrm{dL}$

\section{Pembahasan}

Kasus ini diawali dengan kondisi kejang pada pasien yang terjadi 2 kali (pertama 2 menit, beberapa menit kemudian terjadi lagi selama 10 menit) pada hari ke- 8 pasca seksio sesarea. Tidak diketahui riwayat preeklampsia/preeklampsia berat/eclampsia baik pada kelahiran ini maupun sebelumnya, tetapi pada hasil pemeriksaan laboratorium saat admisi ke UGD didapatkan proteinuria $(+3)$. Secara visual didapatkan sesak (RR meningkat $>36 \mathrm{x} / \mathrm{m}$ ), dengan $\mathrm{X}$-foto toraks terlihat perselubungan dikedua lapang paru, dan $\mathrm{SpO}_{2}$ hanya mencapai $87 \%$ meskipun telah diberikan $\mathrm{O}_{2}$ NRM dengan Jackson Rees 15 lpm. Akral dingin, basah, sianosis, dan tingkat kesadaran menurun.

Secara umum, kondisi kejang pada pasien post partum akan mengarahkan pola diagnosis kita ke eklampsia ${ }^{3}$, terlebih pada pasien ini didapatkan proteinuria $(+3)$, dan kejadian kejang diikuti penurunan kesadaran. Kejadian dural puncture juga berpotensi menyebabkan kejang8,9,10. Tetapi pada pasien ini kedua diagnosis tersebut tidak terdukung secara nyata. Tidak ada hipertensi /riwayat hipertensi, dan tidak ada riwayat yang jelas akan adanya preeklampsia/preeklampsia berat/eklampsia, serta tidak ada kejelasan tentang prosedur anestesi yang telah dilakukan. Karena kondisi desaturasi pasien yang terjadi meskipun telah mendapat terapi oksigen kadar tinggi, maka diputuskan dilakukan lebih dahulu tindakan resusitasi. Langkah awal terapi pada pasien ini adalah dukungan airway-breathing-circulation. Pasien di-intubasi, diberikan ventilasi mekanik, dan dukungan kardiovaskuler.

Dalam upaya pengendalian airway-breathing pasien ini terdapat penyulit. Pengaturan ventilasi mekanik yang diperkirakan seharusnya cukup adekuat untuk memberikan hasil oksigenasi yang baik, ternyata tidak tercapai. $\mathrm{SpO}_{2}$ tidak lebih dari $88 \%$ pada $\mathrm{FIO}_{2} 100 \%$. Sayang sekali, tehnik recruitment paru sangat berisiko dikerjakan karena kondisi hemodinamik yang cukup kritis, yaitu laju nadi $160-180 \mathrm{x} / \mathrm{m}$ pada tekanan darah 100-120/70-80 $\mathrm{mmHg}$ (sudah terpasang norepinephrine $0,1 \mu \mathrm{g} / \mathrm{kgBB} / \mathrm{jam}$ ), serta pernah terjadi episode shock, yang meskipun telah dilakukan pemberian cairan resusitasi, masih belum meyakinkan kestabilannya. Terlebih ketika didapatkan sputum pink-froothy yang makin mengarah ke kondisi kemungkinan edema paru / overload cairan, maka timbul pertimbangan bahwa masalah pada oksigenasi pasien ini dapat terkait langsung dengan masalah kardiovaskular (preload, contractility, atau afterload). Kemudian diberikan heparin sejalan dengan hasil pemeriksaan d-dimer yang mengarah ke prokoagulasi, untuk membantu mengurangi kemungkinan gangguan sirkulasi darah paru akibat koagulasi (yang juga dapat menyebabkan desaturasi). Untuk upaya optimalisasi oksigenasi, pernapasan pasien dikendalikan dengan ventilator yang disertai pemberian relaksan otot, sedasi midazolam, dan morfin. Morfin berfungsi juga sebagai vasodilator pembuluh darah paru, berpotensi mengurangi edema yang diakibatkan tekanan kapiler paru yang tinggi.

Upaya lebih jauh dalam melakukan evaluasi kardiovaskuler dengan cara invasif, yaitu pemasangan CVC di subclavicula, terhalang risiko pneumothorax yang akan memperburuk oksigenasi. Evaluasi kardiovaskular dengan pemasangan arterial line tidak dimungkinkan karena fasilitas tidak tersedia. Evaluasi kardiovaskuler kemudian dilakukan dengan echocardiography oleh spesialis jantung. Dokter spesialis jantung sebelum melaksanakan 
echocardiography, memberikan obat ivabradine untuk memperbaiki irama jantung, membantu amiodarone yang telah diberikan lebih awal. CVC kemudian tetap dipasang, bukan sebagai alat monitoring/diagnostik, tetapi untuk jalur intravena yang lebih adekuat, dan ditempatkan di arteri femoralis. Pemasangan CVC ini dikerjakan setelah selesai intubasi, sekaligus diambil pula spesimen pemeriksaan darah dan sputum.

Untuk tetap menjaga kestabilan hemodinamik sekaligus mempertahankan fungsi ginjal yang diduga mulai terganggu (produksi urine sempat menurun), diberikan dobutamine. Efek inotropiknya diharapkan membuat tekanan darah cukup untuk kerja glomerulus, dan dikombinasikan dengan kerja norepinephrine sebagai kendali terhadap vasodilatasi berlebihan akan membantu filtrasi glomerulus dengan efek vasokonstriksi glomerulus post capilair. Upaya ini menunjukkan hasil yang cukup memuaskan yang terlihat dari volume urine yang lebih baik dan tekanan darah yang lebih stabil setelah pemberian obat-obat tersebut. Gangguan aliran darah pada sistem gastrointestinal dapat menyebabkan gangguan peristaltik dan ini diduga mulai terjadi karena terdapat retensi di pipa nasogastrik. Untuk membantu masalah ini diberikan pantoprazole dan metoclopramide. Evaluasi lanjutan terhadap retensi tersebut menunjukkan tidak ada lagi retensi cairan lambung.

Saat pemeriksaan luar menyeluruh didapatkan juga masalah berupa lesi di daerah payudara, yang dicurigai sebagai mastitis. Karena terjadi hipertermia, diusulkan kepada DPJP spesialis Kebidanan dan Kandungan untuk diberikan bromocriptine terkait kondisi mastitis tersebut. Dengan pertimbangan bahwa riwayat kejang pasien belum dapat disingkirkan dari kemungkinan proses intrakranial, sedangkan bromocriptine berisiko efek samping terjadi edema cerebri, maka DPJP menunda sementara pemberian bromocriptine. Evaluasi kondisi pasien menjadi lebih terbantu pula oleh peran dokter spesialis paru. Evaluasi ini diperlukan karena oksigenasi yang belum juga ada perbaikan sekalipun hemodinamik membaik, namun suhu tubuh masih cenderung tinggi, dan $\mathrm{X}$-foto paru menunjukkan perselubungan kedua paru. Dokter spesialis paru menyimpulkan bahwa Mendelson syndrome belum dapat disingkirkan, sehingga menambahkan antibiotika lain berkombinasi terhadap levofloxacine, yaitu Meropenem 3x 1 gram, dan diberikan juga indexon $2 \times 6 \mathrm{mg}$, bisolvon $3 \times 4 \mathrm{mg}$, dan furosemide $3 \mathrm{mg} / \mathrm{jam}$. Suhu tubuh membaik selama 3 jam pertama di hari perawatan kedua, tetapi kemudian beranjak naik, sehingga diputuskan paracetamol dikombinasikan dengan metamizole 2 x $500 \mathrm{mg}$. Obat ini dipertahankan sejalan dengan makin menurunnya suhu tubuh pasien secara bertahap ke suhu normal. Selanjutnya, meskipun belum dapat dilakukan evaluasi CT-scan terhadap kemungkinan edema cerebri, berdasarkan penilaian gejala dan tanda fisik, DPJP spesialis Kebidanan dan Kandungan memutuskan memberikan bromocriptine untuk menyingkirkan kemungkinan bahwa kenaikan suhu bersumber dari mastitis. Pemeriksaan CT-scan dan MRI pada beberapa kasus kejang post partum dapat membantu menegakkan diagnosis, ${ }^{4-6}$ tetapi karena tidak didapatkan tanda maupun gejala gangguan neurologis maka pemeriksaan CT-scan dan MRI ini menjadi pertimbangan untuk tidak dilakukan.

Pemeriksaan echocardiography kemudian menyimpulkan adanya cardiomyopathy, yang karena telah diberikan ivabradine dan dengan makin terkendalinya suhu tubuh, nadi, dan tekanan darah, maka mulai dilakukan tappering-off : dosis norepinephrine diturunkan secara bertahap, amiodarone diselesaikan sesuai program, ivabradine direncanakan dihentikan untuk berganti ke digoxin, rocuronium diturunkan dan dihentikan, $\mathrm{FIO}_{2}$ dikurangi, dan feeding enteral dengan enterasol dimulai. Kelainan kondisi elektrolit diupayakan diperbaiki. Sempat terjadi takikardia kembali, tetapi langsung diantisipasi dengan pemberian digoxin, dan kemudian nadi terjaga kembali kearah normal. Pemeriksaan mikrobiologi kemudian menunjukkan tidak ada kuman/pertumbuhan kuman pada spesimen sputum maupun darah yang telah diambil pada saat pasien masuk ICU dihari pertama. Selanjutnya karena kondisi pasien dinilai telah cukup baik dan oksigenasi telah adekuat, maka dimulailah proses weaning ventilator pada hari 
ke-4. Secara bertahap rencana tappering off obat dilanjutkan, dan sebagian dikonversi ke bentuk tablet. Secara ringkas bahwa pada pasien ini yang semula diduga terjadi eklampsia, tetapi karena perubahan hemodinamik yang tidak mengarah ke diagnostik eklampsia, maka terjadi kesulitan dalam menegakkan diagnosis definitif. Dengan tetap memperhatikan beberapa kemungkinan yang bisa menyebabkan kejang, baik intrakranial maupun ekstrakranial, maka dilakukan upayaupaya supportive dan terapi simptomatis mulai dari terapi terhadap kondisi desaturasi, terapi terhadap gangguan irama jantung (takikardia, SVT) dan kardiomiopati, terapi terhadap kemungkinan Mendelson syndrome, terapi terhadap hipertermia (ada mastitis), terapi elektrolit, maupun supportif terhadap kerja gastrointestinal dan fungsi ginjal. Dengan mengerjakan terapi-terapi supportif dan simptomatis diatas, sekaligus mengupayakan ekslusi satu demi satu kandidat diagnosis, pasien ini ternyata dapat terbantu dan pulih ke kondisi yang baik dan stabil.

\section{Simpulan}

Pada pasien ini kami menarik kesimpulan bahwa penyebab utama kejang berasal dari masalah kardiovaskular, yang kemudian mengganggu fungsi kerja otak, dan menyebabkan terjadi kejang. Kesimpulan ini kami ambil mengingat bahwa dalam rangkaian terapi terhadap pasien ini, terapi kardiovaskular secara menonjol memberikan pengaruh positif terhadap disfungsi organ pasien, dan bahwa lama terapi/perawatan pasien cukup pendek yang sering menjadi ciri dari perawatan pasien kritis dengan gangguan kardiovaskuler sesaat. Untuk pasien ini masih perlu dilakukan assessment lanjutan terutama bila ada perencanaan kehamilan berikutnya.

\section{Daftar Pustaka}

1. Tantillo GB, Jetté N, Yoo JY, Stone J, Egerman M, Dhamoon MS. Pregnancyrelated complications and risk of postpartum readmission for seizures and epilepsy: A national study. Epilepsia, 2020; 61(9):1990-8
2. Hunt D, Crane D, Brown S. Postpartum Seizures. 2018 [cited 2021 Aug 14]. Tersedia dari https:/www.emra.org/emresident/ article/postpartum-seizures/

3. Bin Idu M, Wei Chieh Tan J. Rare case of late post-partum seizure preceding peri-partum cardiomyopathy presentation. Ann Cardiol Cardiovasc Med. 2020; 4(1): 1034

4. James J, Jose J. Postpartum Woman with seizures. Images In Emergency Medicine. 2017;69(1): 151.

5. El Ameen NA, Amin MF, Kotb A. MRI of the brain in postpartum convulsions; pose diagnostic dilemmas. The Egyptian Journal of Radiology and Nuclear Medicine. 2017;48(4): 999-1004

6. Reynaud Q, Killian M, Tardy B. An uncommon case of post partum seizures. Internal medicine flashcard. 2015;26(9): E41-2.

7. Chhabra A, Jagtap S. Postpartum seizures with posterior reversible encephalopathy syndrome following cesarean delivery for triplets. Journal of Obstetric Anaesthesia and Critical Care. 2014;4(1): 50-2.

8. Jamadarkhana S, Law RC. Seizures in the early post-partum period: A diagnostic dilemma. Indian J Anaesth. 2012; 56(2): $183-5$

9. Ng MD, Manikappa S. Postpartum seizure and ischaemic stroke following dural puncture and epidural blood patch. Anaesth Intensive Care 2012; 40: 347-51

10. Dogani R, Horasanlf B, Ozcimen EE, Basarani B, Kaya Y. A case of postpartum seizures following spinal anesthesia an epidural blood patch. Gynecol Obstet Reprod Med. 2011;17(2):110-2 